\title{
The relationship between psychological and physiological stress perceived by elite shooters
}

\author{
Sang-hyuk Park', Jae-youn Jeon', \& Seung-taek Lim²* \\ ${ }^{1}$ Korea Institute of Sports Science \& ${ }^{2}$ Kangwon National University
}

\begin{abstract}
[Purpose] The purpose of this study was to provide useful information on the improvement of performance by measured the psychological-physiological stresses experienced by elite shooters during a competition. [Methods] Thirty-eight elite shooters participated in this study (Male $=13$, Female $=25$ ). Psychological stress was measured and used for this study based on the stress factors found in the elite target stress study by Park(2015). The cortisol, a physiological stress hormone, was measured using saliva. [Results] The reliability of the psychological stress sub-factor pre-post analysis results showed no statistically significant. The concentration of cortisol measured on the day before the competition $(0.1704 \mu \mathrm{g} / \mathrm{dL})$ significantly increased immediately before the competition $(0.3558 \mu \mathrm{g} / \mathrm{dL})$. Cortisol immediately before the competition showed negative correlation $(\mathrm{r}=-.361, \mathrm{p}=.036)$ with the competition score, and the regression variable of cortisol was 13\%. [Conclusions] In this study, physiological stress had a negative effect on elite shooters performance compared to psychological stress.
\end{abstract}

Key words: shooting, elite athletes, stress, cortisol, improving performance

\section{서 론}

시합에 출전하는 선수들은 최고수행의 조건들을 유지 하기 위해 심리적-생리적 요인들의 변화를 억제하고, 안 정적으로 유지하면서 선수 개인이 설정한 목표를 달성할 수 있도록 노력한다. 이러한 과정에서 선수들은 예측할 수 없는 상황을 맞이하게 된다. 시합 상황에서 선수들은 최상수행(peak performance)의 경기력을 위해 최선의 노력을 하지만 선수는 부상뿐만 아니라 다른 요인으로 인 해 선수가 가지고 있는 충분한 능력을 발휘하지 못 하는 경우도 있다. 특히 시합에 영향을 미치는 다양한 요인 중 스트레스(stress)는 선수들에게 항상 존재하고 있으며, 심리적 상태에 많은 영향을 미치는 주요 요인이 된다. 선

논문 투고일 : 2020. 02. 03.

논문 수정일 : 2020. 03. 12.

게재 확정일 : 2020. 04. 22

* 교신저자 : 임승택(limdotor@gmail.com).
수들이 시합 시 경험하는 스트레스는 보편적인 관점에서 부정적인 의미로 사용되며, 시합으로부터 경험되는 자극 과 시합 중 경험하는 돌발 상황에 대한 지각 및 시합 결과 에 대한 반응에 핵심적으로 사용되고 있는 심리적 개념이 다(Levine et al., 1991).

모든 경기상황에서 발생 된 스트레스가 만성적으로 과 도하게 증가하게 되면 주의집중, 에너지 소모, 운동의 효 율성, 협응력, 각성과 같은 심리-생리적 반응에 부정적인 영향을 미치고, 이로 인해 경기력 저하는 물론 근 긴장이 높아져서 상해의 위험성이 커져 심한 경우 경기를 지속할 수 없게 된다(Smith, 1986). 이에 따라, 선수들은 성공 적인 결과를 얻기 위해 시합 전 다양한 스트레스 조절 방 안을 찾기 위해 노력한다(Freitas et al., 2014). 본 연구 의 대상인 사격 선수들을 비롯한 많은 엘리트 스포츠 선 수들이 시합 때 경험하는 스트레스에 대처하는 방법은 최 근까지 선수와 지도자 및 그 밖의 많은 학자들의 관심을 
끌고 있다(Sallen et al., 2018). 그 중 많은 선행연구들 은 스트레스 관리 기술이 운동 수행력 및 경기력과의 관 계가 있음에 초점을 맞추고 있다(Clark et al., 2016; Nédélec et al., 2015). 선수가 스트레스에 직면하면 일 반적으로 경기력이 떨어지는 부정적인 경험을 하게 된다 (Guo et al., 2019). 스트레스와 관련된 학자들의 초기 정의들은 스트레스가 환경지각과 능력지각의 불균형의 과정이라고 정의하고 있다(McGrath, 1970). 즉, 사람들 은 환경적 요구가 자신의 능력보다 크거나 자신을 위협하 는 것으로 느낄 때 스트레스를 느끼게 된다(Han, 2003; Lazarus \& Folkman, 1984a, 1984b). 그리고 개인이 상황적 요구에 대해 자신의 능력을 부정적으로 평가할 때 스트레스가 발생되어 긴장, 짜증 및 피로를 유발하게 된 다(Smith, 1986). 이러한 스트레스와 관련하여 많은 연 구가 이루어져 왔으며, 일부 연구자들(Han, 2003; Hellgiegel \& Woodman,1992; Park et al., 2012; Selye, 1984)은 선수들이 경험하는 스트레스가 경기력 뿐 만 아니라 만성질환을 유발하는 주요 원인으로 보고하 였다.

스트레스는 단순히 심리적 반응에 제한되지 않고 스트 레스의 부정적 범위를 확장시켜 뇌 활동에 부정적 영향을 미치고 이는 중추신경계(central nervous system; CNS)에 영향을 미친다(Foley et al., 2019). 이는 뇌 대 사에서 일어나는 각성과 인지 기능의 변화, 행동 변화, 그 리고 근 긴장의 증가와 함께 내분비와 면역 체계의 변화 를 동반한다(Cohen et al., 2007). 따라서 생리적 관점 에서의 스트레스는 시상하부 근방핵(paraventricular nucleus; PV)에서 시상하부를 순환하여 코티코트로핀 방출 인자에 영향을 미쳐(corticotropin- releasing factor; $\mathrm{CRF}$ ), 전방 뇌하수체 및 글루코코틴(cortisol)의 방출을 유도한다(Owens et al., 1991). 이러한 이유로, 스트레스는 심리적 반응뿐만 아니라 생리적으로 반응을 일으키게 된다. 선행연구에 의하면 엘리트 성인 선수 및 청소년 선수 모두 심리적 스트레스가 시합에 영향을 미치 는 것으로 보고가 되고 있다. 시합 전 레슬링 선수들의 체 중감량이 체중감량 전에 비해 스트레스가 증가하는 것으 로 보고하였으며(Park et al., 2014), 알파인 스키선수 들의 경우 시합 기간 중 심리적 스트레스가 증가하는 것 으로 보고하였다(Davis et al., 2019). 또한 청소년 복싱
선수들이 시합에 대해 자신감이 스트레스에 대한 인지평 가와 비교하여 불안과 흥분 정서를 촉진시키는데 기여한 다고 하였다(Lee, 2013). 무용전공 중학생들의 경우 스 트레스는 무용몰입과 탈진에 유의한 영향을 주고 있어 스 트레스를 극복할 수 있는 심리적인 대처 전략과 심리기술 이 마련되어야 한다고 보고하였다(Youm, 2019). 대학 운동선수들의 경우 스트레스 수준에 따라 운동내적동기 의 긴장과 지속수행의 유의한 영향을 주고 있음을 보고하 여 스트레스와 운동내적동기 및 운동지속수행의 관계는 서로 밀접하다고 보고하였다(Kwon et al., 2015).

또한 생리적 스트레스가 시합에 미치는 영향에 대해 많은 선행연구들이 보고 되고 있는데, 엘리트 청소년 태 권도 선수들의 경우 시합 직전 생리적 스트레스 호르몬인 cortisol이 증가하여 스트레스가 증가하였다고 보고하였 다(Capranica et al., 2017). 또한, 울트라 마라톤 중의 스트레스 호르몬인 cortisol의 농도를 관찰한 결과 $10 \mathrm{~km}$ 지점에서 $29 \%, 25 \mathrm{~km}$ 지점에서 $29 \%, 50 \mathrm{~km}$ 지점에서 $56 \%$ 그리고 $100 \mathrm{~km}$ 지점에서 $17 \%$ 의 cortisol 농도 향상 을 보고하였다(Deneen et al., 2017). 엘리트 양궁 선수 들을 대상으로 경기력에 따라 우수 그룹과 비 우수 그룹 으로 나누어 조사한 결과 시합 전 30 분의 cortisol의 농도 는 비슷하였으나, 시합 직전 3분과 시합 후 30에 있어 비 우수 그룹의 cortisol의 농도가 유의하게 높은 것을 보고 하였다(Lim, 2018)

이렇듯 사격 선수들뿐만 아니라 운동선수들은 시합과 여러 외부적인 요인에 의해 심리적 및 생리적 스트레스가 증가한다. 더욱이, 사격 경기는 이러한 스트레스의 관리 가 경기력 향상에 직접적 관련이 된다. 사격경기는 총을 이용해 정해진 거리에서 격발하여 표적지 중앙에 가까이 위치시키는 가를 결정하는 기록경기로서, 자세, 호흡, 조 준, 격발, 추적으로 연속성을 가지며, 체력과 정신력, 심 리적 상태의 조화가 이뤄졌을 때 높은 기록이 가능하다 (Lim \& Kim, 1983).

고도의 집중력을 요구하는 종목의 특성상 미세한 스트 레스에도 부정적인 심리변화가 나타나며, 선수는 경쟁적 인 사격경기 상황에 노출되었을 경우 여러 가지 정서적 감정을 보이며, 경기상황에서 생리적, 심리적으로 다른 특징을 나타낸다. 이러한 스트레스의 작용은 실제 사격 시합에서 시합 전략 오류를 야기하고, 결과적으로 성공적 
인 시합 결과를 이끌어내는데 큰 방해가 된다. 이러한 근 거는 실제 현장의 선수들과 지도자들이 호소하는 문제였 다. 보편적으로 사격경기에서 많은 선수들은 심리적 요인 에만 집중하여 생리적 요인을 간과하는 측면이 있었다. 긴장이나 불안 및 스트레스 등 시합 시 경험하는 심리적 어려움으로 인하여 부정적인 시합결과가 나타난다는 생 각에 긴장이나 스트레스 등의 심리적 요인의 조절 및 완 화에만 치중하여 생리적 반응을 외면하게 되고 이러한 과 정에서 부정적인 시합결과를 초래하게 된다는 것이다.

따라서 본 연구의 필요성을 지지하는 선행연구를 살펴 보면 다음과 같다. 먼저 Mehrsafer et al(2019)은 경기 력 저하에 영향을 미치는 스트레스 감소를 위한 시합 전 날 심리명상훈련을 실시하여 생리적 스트레스 호르몬의 감소를 보고하여 시합상황에 대한 심리적-생리적 스트레 스 반응이 감소하였다고 보고하였다. 또한 23 명의 사이 클 선수들을 대상으로 조사한 결과 시합전의 심리적 손상 은 경기력 저하에 직접적이므로, 시합 전 심리적 손상이 되는 인지노력(cognitive effort)를 줄여 경기력 향상을 시켜야 한다고 보고한 연구(Filipas et al., 2019)가 발 표된 바 있으며, 더욱이 특정 시합 및 고강도 훈련 전의 사격 선수들이 제어와 관련하여 대뇌 피질의 효과적 과정 과 관련되어 있다는 연구(Haufler et al., 2000)도 발표 된 바 있다. 이러한 관계는 시합 또는 연습이라는 다른 조 건 사이에 사격 과녁을 조준하는 동안 코르티코(cortico, 피질)-대뇌 피질 (cortical) 사이의 소통의 차이가 있기 때 문이다(Woo \& Kim, 2017).

따라서 이러한 선행연구를 살펴볼 때 심리 혹은 생리 적 요인 하나의 영역에만 국한하지 않고 심리적 생리적 요인을 통합적으로 고려하여 분석하는 것은 선수들의 경 기력 향상 뿐만 아니라, 스트레스에 대한 이해를 높이는 데 중요한 정보를 제공할 수 있다. 본 연구의 목적은 엘리 트 사격 선수들이 경험하는 시합 시 심리 스트레스와 cortisol의 변화를 알아보고 경기력(시합 점수)에 미치는 심리 스트레스와 cortisol의 영향력을 검증하고, 경기력 향상에 유용한 정보를 제공하기 위한 목적이 있다.

\section{연구방법}

\section{연구대상}

본 연구의 대상은 권총 및 소총 국가대표 및 엘리트 사 격 선수 38명을 대상으로 선정하였다. 모든 대상자는 타 액을 통한 스트레스 측정을 위하여 다음 항목에 해당되는 대상으로 선정하였다.

(1) 심장, 폐 또는 신진대사 장애가 없는 사람.

(2) 과거 1 년 이내에 주요 우울증과 양극성 장애의 진 단을 받지 않고, 정신 분열증의 과거(DSM-IV), 최근 3 개월 이내에 불안 및 초조(agitation) 등의 정신 증상이 없으며, 프로토콜의 완료가 가능한 사람.

(3) 사격 시합에 안전하게 참여하지 못하는 근골격계 장애가 없는 사람이며 본 연구에 진행될 검사에 대한 부 작용이 없는 사람. 또한 본인의 의지에 의하여 참여 의사 를 밝힌 자로 실험 전 모든 대상자들에게 서면에 의한 동 의를 구한 후 실시하였다.

대상자의 표본크기는 $G^{*}$ power 3.1.2 프로그램을 이 용하여 중간 수준의 효과크기 0.30 , 유의수준 0.05 그리 고 검정력 0.95 로 산출한 결과 본 연구에 필요한 대상자 수준 26 명으로 나타났다. 실험 참여 거부와 대상자 동의 서 철회 등 탈락률(dropout rate) $20 \%$ 를 고려하여 40명 의 대상자를 모집하였으나, 2 명의 탈락자가 발생하여 최 종 38 명의 대상자의 자료가 연구결과에 활용되었다.

본 연구에 참여한 연구대상자들은 〈Table 1)과 같다.

Table 1. The characteristic of the subjects

\begin{tabular}{cccc}
\hline \hline Value & Male $(\mathrm{n}=13)$ & Female $(\mathrm{n}=25)$ & Total $(\mathrm{n}=38)$ \\
\hline Age (years) & $21.85 \pm 464$ & $24.40 \pm 4.50$ & $23.53 \pm 4.64$ \\
\hline Career (years) & $9.54 \pm 4.58$ & $12.28 \pm 4.57$ & $11.34 \pm 4.57$ \\
\hline \hline mean \pm SD & & &
\end{tabular}

〈Table. 1〉에 제시된 바와 같이 연구대상자들의 특성 은 남자가 13 명, 여자가 25 명이었으며, 나이는 평균 23 세, 경력은 11 년으로 나타났다. 


\section{연구절자}

본 연구의 절차는 2019 년 $\mathrm{C}$ 시에서 개최된 세계사격월 드컵 출전대표 선발전 겸 전국사격대회에 참여한 선수들 을 대상으로 시합 전날과 시합 직전의 심리적 및 생리적 스트레스 측정에 관련한 모든 실험이 수행되었다. 측정 시점은 사전-사후 모두 동일한 시간에 측정되었으며, 각 각의 시점마다 심리적 검사지를 이용한 스트레스 측정과 타액을 이용한 스트레스 측정을 실시하였다. 따라서 실험 특성상 경기가 실시되는 사격 경기장에서 진행되었으며, 연구 참여 대상자들은 본 연구를 위해 2회 참여하도록 요 청되었다.

연구 도식은 아래〈Fig 1 과 같다.

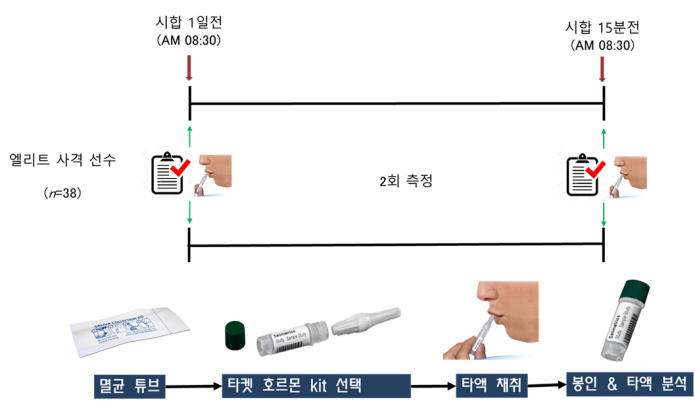

Fig 1. Experimental procedures and methods

\section{측정 항목 및 방법}

\section{심리 스트레스 측정}

심리 검사지를 이용한 스트레스 측정은 박상혁 (2016) 의 엘리트 사격 스트레스 연구에서 탐색 된 스트레스 요 인을 기초로 본 연구에 맞게 설문지를 제작하여 사용하였 다. 사격 선수의 스트레스를 측정하기 위한 설문지는 노 력손실, 결과부담, 컨디션저하, 과도한 긴장, 장비 문제, 집중력 저하, 주요타자의 기대, 훈련부족, 자신감 저하의 요인으로 구성되어 있으며, 각각의 요인 4 5문항을 포 함하는 35문항으로 구성하였다. 또한 엘리트 사격 스트 레스 설문지는 5점 반응(likert scale)로 측정하도록 되 어있다. 사격 선수들의 심리적 스트레스를 측정하기 위하 여 구성된 설문지는 초기 개방형 설문을 통해 엘리트 사 격선수들이 경기에 대한 스트레스를 일으키는 원인을 규 명하고 이를 내용분석을 통해 구조화한 설문지이다. 특히 본 설문지는 사격 선수들을 대상으로 사격정기에 특화된
스트레스를 측정하기에 적합한 설문지로 개발되었다. 설 문지는 시합 전날 공식 훈련 안정 시 1 회와 다음날 시합 직전 1 회로 총 2 회 수집하였다.

사격 심리 스트레스의 신뢰도 분석결과는 아래 〈Table. 2〉와 같다.

Table 2. Pre- and post- reliability analysis results of psychological stress factors

\begin{tabular}{|c|c|c|c|}
\hline Stress factors & Question number & Pre- & Post- \\
\hline Effort loss & No. 1, 2, 3, 4 & .970 & .975 \\
\hline Result burden & No. $5,6,7,8$ & .950 & .981 \\
\hline $\begin{array}{l}\text { Deterioration of } \\
\text { condition }\end{array}$ & No. $9,10,11,12$ & .899 & .911 \\
\hline Overstrain & No. $13,14,15$ & .842 & .855 \\
\hline $\begin{array}{l}\text { Equipment } \\
\text { problems }\end{array}$ & No. $16,17,18$ & .724 & .810 \\
\hline $\begin{array}{c}\text { Decreased } \\
\text { concentration }\end{array}$ & No. 19, 20, 21 & .827 & .873 \\
\hline $\begin{array}{c}\text { Major player's } \\
\text { expectations }\end{array}$ & No. $22,23,24,25$ & .884 & .901 \\
\hline Lack of training & No. $26,27,28$ & .772 & .787 \\
\hline $\begin{array}{c}\text { Loss of } \\
\text { confidence }\end{array}$ & No. $29,33,34,35$ & .851 & .915 \\
\hline
\end{tabular}

〈Table. 2〉에 제시된 바와 같이 심리 스트레스에 대한 신뢰도 분석결과 9개요인 32문항으로 나타났다. 먼저 3 개 문항은 삭제 후 신뢰 계수에서 문항이 요인에 포함될 경우 신뢰도를 감소시키는 것으로 나타나 삭제처리 하였 다. 사전측정에서의 신뢰도와 사후에서의 신뢰도 모두 양 호한 지수를 나타내었다. 또한 사격 선수들의 스트레스 요인은 모두 부정적인 요인이다.

\section{생리적 스트레스 측정}

생리적 호르몬 지표 분석은 타액을 이용하여 측정하였 다. 생리적 호르몬 지표 분석을 위해 채집한 타액은 음식 물 등의 영향을 받을 수 있으므로, 타액 채집 2시간 전부 터는 어떠한 음식물도 섭취하지 못하도록 통제하고, 안정 된 상태에서 채집하였다. 생리적 호르몬 지표는 cortisol 을 측정하였다. 
타액 채집 15 분 전에 입을 깨끗한 물로 가글하도록 하 였으며, 이후, $20 \mathrm{ml}$ 플라스틱 튜브에 $3 \mathrm{ml}$ 선까지 타액을 채집 하였다. 채집이 끝난 플라스틱 튜브는 $-80^{\circ} \mathrm{C}$ 에서 냉 장보관하고 전체적 채집이 끝난 이 후 분석을 실시하였 다. 타액 분비속도는 1 분간에 분비된 타액의 총 중량을 계측하는 것으로 $\mathrm{ml} / \mathrm{min}$ 으로 정량화 하고, 채집된 타액 으로 cortisol은 효소면역분석 방법인 효소결합면역흡착 검사(Enzyme linked immunoassay: ELISA)를 통하여 분석하였다.

\section{통계 처리}

본 연구의 자료처리는 Windows SPSS/PC Ver. 21.0 통계 프로그램을 이용 하였으며, 평균과 표준편차를 산출 하여 제시하였다.

먼저 심리 스트레스와 cortisol의 사전-사후 변화를 알 아보기 위하여 대응표본 T-검증을 실시하였다.

두 번째로 경기력(시합 점수)에 미치는 심리스트레스와 cortisol의 영향력을 알아보기 위하여 상관분석(correlation analysis) 및 다중회귀분석(multiple regression analysis)을 통해 관련성을 검증하였다. 모든 통계학적 유의수준은 $\alpha=0.05$ 로 하였다. 시합점수는 연구 참여자 들의 당시 시합점수를 확보하여 입력한 후 이를 기준으로 분석하였다. 사격경기의 시합 점수는 10 발씩 6 라운드 진 행되며, 전자표적으로 사용함으로 10점에 근접할수록 소 수점으로 순위를 결정하는 형식으로 진행된다. 본 연구의 시합 점수는 시합이 종료된 후 연구에 참여한 선수들의 시합 점수를 확인하여 통계분석에 활용하였다. 본 시합에 서 선수들의 점수는 소총과 권총을 모두 포함하여 경우 최대 610.30점에서 최소 327.70점으로 나타났다.

\section{연구결과}

\section{심리 스트레스 사전-사후 분석 결과}

시합 전날을 사전으로 설정하고 시합 직전을 사후로 설 정하여 심리 스트레스의 변화를 알아보았다. 심리 스트레스 의 대응표본 T검증 결과는 분석결과는 〈Table. 3 >과 같다.
Table 3. Changes in psychological stress of pre- and post- test

\begin{tabular}{|c|c|c|c|c|c|c|c|}
\hline \multirow{2}{*}{$\begin{array}{l}\text { Stress } \\
\text { factors }\end{array}$} & \multicolumn{2}{|c|}{ Pre- } & \multicolumn{2}{|c|}{ Post- } & \multirow{2}{*}{$\begin{array}{l}\text { Pre- } \\
\text { and } \\
\text { post- } \\
\text { change }\end{array}$} & \multirow{2}{*}{$\mathrm{t}$-value } & \multirow{2}{*}{$p$-value } \\
\hline & Mean & $\mathrm{SD}$ & Mean & $\mathrm{SD}$ & & & \\
\hline Effort loss & 3.32 & 1.25 & 3.15 & 1.20 & decrease & 1.832 & .075 \\
\hline $\begin{array}{l}\text { Result } \\
\text { burden }\end{array}$ & 3.23 & 1.13 & 3.17 & 1.17 & decrease & .540 & .593 \\
\hline $\begin{array}{l}\text { Deterioration } \\
\text { of condition }\end{array}$ & 2.73 & 1.06 & 2.67 & 1.03 & decrease & .351 & .728 \\
\hline Overstrain & 2.71 & 1.06 & 2.63 & 1.07 & decrease & .692 & .493 \\
\hline $\begin{array}{l}\text { Equipment } \\
\text { problems }\end{array}$ & 2.89 & .95 & 2.67 & .99 & decrease & 1.67 & .102 \\
\hline $\begin{array}{c}\text { Decreased } \\
\text { concentration }\end{array}$ & 3.15 & 1.00 & 3.02 & 1.00 & decrease & 1.00 & .322 \\
\hline $\begin{array}{c}\text { Major } \\
\text { player's } \\
\text { expectations }\end{array}$ & 2.84 & 1.01 & 2.80 & 1.01 & decrease & .439 & .663 \\
\hline $\begin{array}{l}\text { Lack of } \\
\text { training }\end{array}$ & 3.12 & .90 & 3.05 & .83 & decrease & .758 & .453 \\
\hline $\begin{array}{l}\text { Loss of } \\
\text { confidence }\end{array}$ & 3.20 & 1.00 & 3.17 & 1.00 & decrease & .470 & .641 \\
\hline
\end{tabular}

심리 스트레스 하위요인에 대한 신뢰도 사전 사후 분 석결과 통계적으로 유의확률은 나타나지 않았으나, 시합 전날에 비하여 시합 직전의 스트레스가 감소한 결과가 나 타났다. 또한, 대부분의 요인에서 시합 전날 스트레스보 다 시합 직전의 스트레스가 감소한 것을 알 수 있다.

특히 장비와 관련된 문제로 지각하는 스트레스가 가장 현저한 감소를 나타내었으며, 집중력 저하로 인한 스트레 스와 노력한 만큼 성과가 나타나지 않았을 때 나타나는 스 트레스가 두 번째로 큰 차이로 감소하는 것으로 나타났다. 이러한 분석결과를 그래프로 제시하면 아래〈Fig 2〉와 같다.

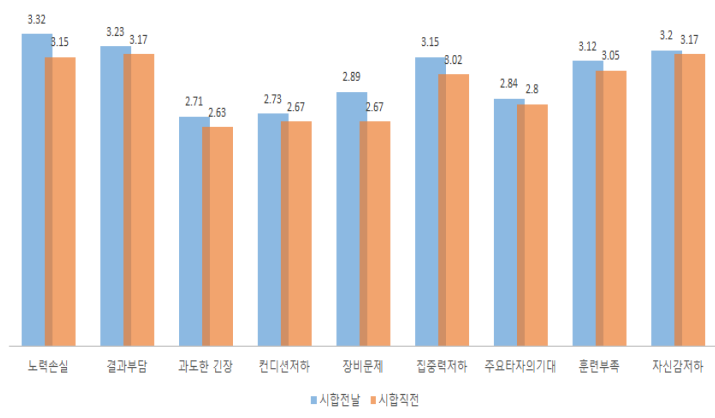

Fig 2. Pre- and post- test analysis graph of psychological stress 
〈Fig 2〉에 제시된 바와 같이 사전에 비하여 사후의 심리스트레스는 오히려 감소하는 것으로 나타났다.

\section{cortisol의 사전-사후 분석 결과}

시합 전날을 사전으로 설정하고 시합 직전을 사후로 설정하여 생리 스트레스인 cortisol의 변화를 알아보았 다. cortisol의 사전-사후 대응표본 T검증 분석결과는 아 래〈Table. 4〉과 같다.

Table 4. Change in cortisol of pre- and post test

\begin{tabular}{|c|c|c|c|c|c|c|c|}
\hline \multirow{2}{*}{$\begin{array}{l}\text { Stress } \\
\text { factors }\end{array}$} & \multicolumn{2}{|c|}{ Pre- } & \multicolumn{2}{|c|}{ Post- } & \multirow{2}{*}{$\begin{array}{l}\text { Pre- and } \\
\text { post- } \\
\text { change }\end{array}$} & \multirow{2}{*}{ t-value } & \multirow{2}{*}{$p$-value } \\
\hline & Mean & SD & Mean & SD & & & \\
\hline Cortisol & .17 & .06 & .35 & .19 & Increase & 6.183 & .000 \\
\hline
\end{tabular}

시합 전날인 사전 cortisol의 농도는 $0.1704 \mu \mathrm{g} / \mathrm{dL}$ 로 나타났으며, 시합 직전의 사후 cortisol 농도는 0.3558 $\mu \mathrm{g} / \mathrm{dL}$ 로 유의하게 증가하였다. 이는 심리 스트레스와는 다르게 생리 스트레스 지표인 cortisol은 유의하게 증가 되었다는 것을 의미한다.

이러한 분석결과를 그래프로 제시하면 〈Fig 3〉과 같다.

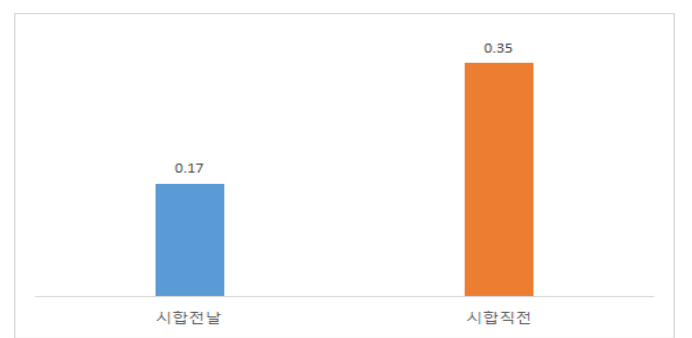

Fig 3. cortisol의 사전-사후 변화 그래프

〈Fig 3〉에 제시된 바와 같이 사전에 비하여 사후의 cortisol은 증가하는 것으로 나타났다.

\section{심리 스트레스와 cortisol이 시합 점수에 미치는 영향}

심리적 스트레스 9개 요인과 생리적 스트레스 지표인 cortisolol 시합 점수에 미치는 영향을 알아보기 위하여
상관분석 및 다중회귀분석을 실시하였다. 시합점수는 권 총과 소총선수의 시합 점수가 동일한 유형으로 나타나기 때문에 시합이 끝난 후 바로 확보하여 코딩(Coding)후 분석하였다. 시합 점수는 1 라운드 10 발씩 총 60 발로서 각 공기소총 점수는 최저 1점에서 최고 10.9점까지 나타 나며, 공기권총의 경우 소수점 없이 1점에서 10점대로 시합점수가 표시된다. 소총의 경우 표적지 중앙에 얼마 만큼, 어느 정도 또는 얼마나 정확히 명중하는지 따라 소 수점까지 달라지지만 보통 500점에서 600점 전후로 시 합점수가 나타난다. 따라서 시합 점수와 심리적 스트레스 및 cortisol의 상관분석을 수행하여 시합 점수와 심리적 스트레스 및 cortisol의 양방향의 관계를 알아보았다. 시 합점수와 심리적 스트레스 및 cortisol 상세한 사전 측정 치와 사후 측정치는 부록 1 과 2 에 제시하였다. 이러한 분 석결과를 요약하여 제시하면 〈Table. 5〉와 같다.

Table 5. Competition score, psychological stress and cortisol correlation

\begin{tabular}{ccc}
\hline \hline Factors & Pre- & Post- \\
\hline cortisol & .137 & $-.361^{*}$ \\
\hline Effort loss & -.123 & -.005 \\
\hline Result burden & -.138 & .004 \\
\hline $\begin{array}{c}\text { Deterioration of } \\
\text { condition }\end{array}$ & -.054 & .094 \\
\hline Overstrain & .077 & .077 \\
\hline $\begin{array}{c}\text { Equipment problems } \\
\text { Decreased } \\
\text { concentration }\end{array}$ & .054 & .233 \\
\hline $\begin{array}{c}\text { Major player's } \\
\text { expectations }\end{array}$ & -.286 & .011 \\
\hline $\begin{array}{c}\text { Lack of training } \\
\text { Loss of confidence }\end{array}$ & -.019 & -.153 \\
\hline \hline
\end{tabular}

Summary of pre- and post- correlation coefficient calculation for competition scores

$* P<.05$

상관분석 결과 시합 직전의 cortisol은 부적 상관 $(\mathrm{r}=-.361, \mathrm{p}=.036)$ 으로 나타나 시합 점수에 부정적인 영향을 미치는 것으로 확인되었다. 
상관분석결과를 기초로 시합 직전의 cortisol이 시합 점수에 미치는 설명변량을 알아보기 위하여 다중회귀 분 석을 수행하였다. 분석결과는 〈Table. 6)과 같다.

Table 6. Results of multiple regression analysis of cortisol affecting competition score

\begin{tabular}{cccccc}
\hline \hline $\begin{array}{c}\text { Criterion } \\
\text { variable }\end{array}$ & Predictor & $\mathrm{R}^{2}$ & $\mathrm{R}^{2} \mathrm{C}$ & $\beta$ & $\mathrm{F}$-value \\
\hline $\begin{array}{c}\text { Competition } \\
\text { score }\end{array}$ & $\begin{array}{c}\text { psot- } \\
\text { cortisol }\end{array}$ & .361 & .130 & -.361 & $4.802^{*}$ \\
\hline \hline
\end{tabular}

시합 점수에 영향을 미치는 cortisol의 설명변량은 $13 \%$ 로 나타났다. 결과적으로 cortisolo이 증가하면 시합 점수는 낮아진다는 것으로 해석할 수 있다.

\section{논 의}

여러 스포츠 상황에서 선수들이 경험하는 다양한 심리 적-생리적 변화들은 그들의 심리적 특성을 아우르는 동 시에 개인적 성장을 넘어 경기력에 영향을 미치는 절대적 요인으로 작용한다. 선수들이 지각하는 경기력 즉 시합에 대한 승리의 욕구는 선수들 스스로가 자기조절을 기반으 로 매우 복잡하고 다양한 변화를 야기한다. 보편적인 관 점에서'어떻게 하면 시합에서 승리할 수 있을 것인가?'에 대한 물음은 이내 많은 스포츠 과학자들에 의해 시합을 지배하는 요인을 찾고 이를 조절하는 연구로 확대되어져 왔다.

선수들은 시합을 앞두고 최상의 컨디션을 유지하기 위 해 심리적·생리적 안정을 가장 중요하게 생각한다. 이것 은 실제 시합 상황에서 선수들이 추구하는 심리적-생리 적 안정성과 연결되어 있으며, 훈련상황에서 얻는 기능과 노력들을 시합에서 모두 발현되기 위한 전략에 기초한다 (Coutts et al., 2007). 본 연구는 이러한 전략을 강구하 고 확인하는데 필요한 정보를 제공하고자 이루어졌다. 따 라서 국가대표 사격 선수 40명을 표집하여 중도 탈락한 2 명의 대상을 제외하고 38 명에게 얻은 심리적-생리적 지 표 자료를 기초로 사격 경기에 가장 많은 영향을 미치는
스트레스의 심리적-생리적 반응을 동시에 측정하여 이들 관계가 어떠한 구조를 갖는지와 심리와 생리 스트레스 중 어떤 요인이 시합에 가장 많은 영향을 미치는지 알아보고 자 하였다.

분석결과 시합 전날의 심리 스트레스보다 시합 직전의 스트레스가 오히려 감소하는 것으로 나타났다. 시합 시 선수들이 경험하는 스트레스는 심리적 영향뿐만 아니라 근 긴장, 혈압상승, 호흡곤란 등의 생리적 반응과 불안과 우울, 분노, 집중력 저하 등과 같은 심리적 반응을 동시에 유발하는 변인으로 보고되고 있다(Hellgiegel \& Woodman, 1992; Selye, 1984). 또한 협응력, 에너지 소모, 운동의 효율성에 부정적 영향을 미친다고 보고되고 있다(Lazarus \& Folkman, 1984a). 그러나 본 연구에 서는 이러한 선행연구의 가정과는 다른 결과를 나타낸 것 이다. 또한 이러한 결과는 Han el al.(2011)과 Park \& $\operatorname{Jung}(2006)$ 의 연구결과와 다른 것으로 나타났다. 일반 적으로 지금까지의 선행연구들은 시합이 다가옴에 따라 스트레스도 점진적으로 향상되는 것으로 보고된 바 있다. 그러나 본 연구의 결과가 종목 특성에 기인하더라도 선수 들이 지각하는 스트레스 수준은 시합이 다가옴에 따라 증 가하다가 시합 직전에 감소 되는 것은 의외의 결과라고 생각할 수 있다. 이러한 결과는 실제 사격 시합에 참여하 는 선수들이 스트레스에 대해 잘못된 지각을 하고 있다는 것을 증명하는 결과로 해석할 수 있다. 또한 스포츠 현장 에서 관찰 되는 내용으로 살펴보면 실제로 사격 선수들은 심리적 스트레스 감소를 위하여 심리기술훈련에 기반한 스트레스 감소 전략을 활용하고 있다. 이에 심리적 스트 레스에 대한 대처전략은 보편적으로 효과를 나타냈다고 볼 수 있으나, 생리적 스트레스에 대한 대응 전략은 아직 구축되지 못했거나 그 영향력을 간과한 결과라고 해석 해 볼 수도 있다.

그러나 생리적 스트레스 지표인 cortisol의 경우 시합 전 날보다 시합 직전에 매우 급격하게 증가하는 것으로 나타 나, 심리적 스트레스와 상반된 결과를 나타냈다. cortisol 은 부신피질에 의해 분비되어 혈액으로 방출되는 콜레스테 롤로부터 합성된 글루코코르티코이드(glucocorticoid)이며, 스테로이드 호르몬이다(Bozovic et al., 2013). 이미 알 려진 바와 같이, cortisol 분비는 급성 스트레스 상태에서 크게 증가한다(Dickerson et al., 2004; Kirschbaum et 
al., 1994; Shields et al., 2016; Singer et al., 2017). 따라서 이러한 cortisol의 증가는 사격 선수들이 매우 높 은 수준의 생리적 스트레스를 경험하고 있다고 판단된다. Cortisol의 분비와 관련된 Burke et al.(2005)의 연구에 의하면 개인이 어떤 과제를 수행하거나 변화된 환경에서 신체적, 심리적 및 사회적인 안정성을 유지할 수 있게 다 양한 생리적 반응이 나타나며, 이러한 경우 인지된 스트 레스는 중추신경계(central nervous system; CNS)를 활성화시켜 시상하부에서 코르티코트로 핀 방출 호르몬 (corticotropin releasing hormone; $\mathrm{CRH}$ ), 뇌하수체 전 엽에서 부신피질 자극호르몬(adrenal corticotrophic hormone; $\mathrm{ACTH}$ ), 그리고 부신피질에서 cortisol을 분 비하게 됨으로서 높은 심박수와 미세한 근 떨림, 호흡의 불안정성 등을 수반하게 된다. 이 과정에서 $\mathrm{HPA}$ 의 활동 은 세포 외액(혈액, 소변, 타액)의 cortisol 농도 수준을 결정한다(Gozansky et al., 2005). 또한 볼링선수들을 대상으로 안정시, 경기 전, 경기직후의 코티졸 변화를 살 펴본 $\mathrm{Ko}$ (2016)의 연구에 의하면 경기 직전의 코티졸이 증가하는 것으로 본 연구의 동일한 결과를 지지하고 있으 며, 특히 Cortisol과 경기스코어의 밀접한 관계가 있는 것으로 보고하여 본 연구의 결과와 유사한 맥락의 결과를 보고하였다. 결과적으로 사격 선수가 시합에 출전하여, 수행하는 과정에서 선수들은 심리적 스트레스보다 생리 적 스트레스를 더욱 많이 경험하는 것으로 나타났다. 즉 대부분의 엘리트 사격 선수의 경우 모든 선수들이 심리적 스트레스는 감소하였으며, 생리적 스트레스 지표인 cortisol은 증가하는 것으로 나타나 생리적 스트레스 또 한 생리적 스트레스만큼 시합에 영향을 크게 미칠 수 있 다는 것을 예측할 수 있다.

따라서 시합 점수에 영향을 미치는 심리-생리 스트레 스 지표를 알아본 결과 시합 직전의 cortisol은 시합 점수 에 부정적 영향을 미치는 것으로 확인되었다. 즉 시합 직 전의 cortisol이 높아지면 시합 점수는 낮아지는 것으로 판단된다. 시합전날의 스트레스는 시합에 영향을 미치지 않았으며, 이러한 결과는 $\mathrm{Ko}$ (2019)와 $\mathrm{Oh}(2018)$ 의 연구 와 유사하게 나타났다. 분석결과에서도 스트레스 호르몬 인 cortisol과 사격 점수의 부적 상관 $(\mathrm{r}=-.361$, $\mathrm{p}=.036)$ 이 나타났으며, 다중회귀분석에서도 $13 \%$ 의 유 의미한 영향을 미치는 것으로 확인되었다. 운동선수들은
평상시보다 경기 전 불안을 더욱 느낀다(Filaire et al., 2007). 이는 cortisol은 위협적인 자극의 결과로 분비되 기 때문에, 시합은 불안을 불러일으키는 상황으로 간주되 기 때문이다(Casto et al, 2017). 더욱이 이러한 상황은 경기력에 직접적으로 악영향을 주게 된다.

선행연구를 살펴보면 12 명의 유도선수를 대상으로 소 속 지역 내 대회와 지역 외 대회 전, cortisol 농도와 심리 적 스트레스를 조사한 결과, 평상시의 cortisol 농도보다 소속 지역 내 대회에서 $4.5 \mathrm{nmol}$, 지역 외 대회에서 $9 \mathrm{nmol}$ 로 증가된 것으로 나타났으며, 인지적 및 신체적 불안과 cortisol과 정적 상관을 보고하였다(Filaire et al., 2001). 23명의 엘리트 테니스 선수들을 대상으로 조 사한 결과, cortisol 농도와 인지 불안과의 정적 상관관 계, cortisol 농도와 자신감과 부적 상관관계를 보고하였 다(Lautenbach et al., 2014). 사격종목 특성 상 근떨림 이나 호흡 등과 같은 신체적 요인에 상당히 영향을 미친 다고 판단 할 때 시합 전에 코티졸의 급격한 분비는 생리 적인 스트레스 반응(호흡불균형 등)에 영향을 미치고 이 러한 반응이 경기력에 영향을 미쳤다고 해석 할 수 있다. 또한 심리적 스트레스에 대한 대처 전략은 사격 종목 특 성상 일부 견고하게 구축되어 있다고 볼 수 있으나, 생리 적 스트레스의 경우 이런 대처방법의 부재나 인지를 하지 못하는 이유로 시합에 영향을 많이 미치는 것으로 해석해 볼 수 있다. 그러나 이러한 결과는 코티졸이 단순히 스트 레스에 의해서만 야기된다고 보기에는 무리가 있다. 즉, 신체적 컨디션이나 환경 및 경기 시간, 수면에 영향을 받 게 되므로, 이러한 결과를 모든 사격선수들에게 일반화하 기에는 큰 무리가 있다고 판단된다. 따라서 이러한 연구 결과는 본 연구에서 분석된 결과에 한정하여 설명할 수 있으며, 일부 선행연구에서 발견되고 있는 것에 기초할 때 생리적 스트레스는 사격 선수들의 시합에 영향을 미치 는 것으로 판단된다.

\section{결론 및 제언}

본 연구는 38명의 엘리트 사격 선수들을 대상으로 선 수들이 시합 시 경험하는 심리적-생리적 스트레스의 변 화를 알아보고 경기력 수준에 따른 스트레스의 차이와 시 
합 점수에 미치는 스트레스 요인을 알아보는 목적으로 수 행되었다.

첫째, 심리적 스트레스의 사전-시후 분석결과 통계적 유의차는 발견되지 않았으나, 시합 전날에 비하여 시합 직후의 심리적 스트레스는 감소하는 것으로 나타났다.

둘째, 생리적 스트레스 지표인 cortisol의 사전-사후 분석결과 통계적으로 유의미하였으며, 시합 전날에 비하 여 시합 직전에 cortisol은 증가하는 것으로 나타났다.

셋째, 시합 점수의 영향을 미치는 심리적-생리적 스트 레스 요인을 알아본 결과 시합 직후의 cortisol이 시합 점 수에 부정적 영향을 미치는 것으로 확인되었다.

위의 결론을 기초로 후속 연구를 위한 제언은 다음과 같다. 본 연구에서는 생리적 스트레스가 심리적 스트레스 에 비하여 선수들의 경기력에 부정적 영향을 미치는 것으 로 나타났으므로, 추후 생리적 스트레스를 감소시킬 수 있는 전략을 구축하는 연구가 필요할 것으로 생각된다.

\section{참고문헌}

박상혁(2016). 권총및 소총사격 선수들의 경기력 향상을 위한 시합스트레스 및 스트레스 대처 방안 탐색. 미간행 보고 서, 한국스포츠개발원.

Bozovic, D., Racic, M., \& Ivkovic, N. (2013). Salivary Cortisol levels as a biological marker of stress reaction. Medical Archives, 67(5), 374-377.

Burke, H. M., Davis, M. C., Otte, C., \& Mohr, D. C. (2005). Depression and cortisol responses to psychological stress: a meta-analysis. Psychoneuroendocrinology, 30(9), 846-856.

Capranica, L., Condello, G., Tornello, F., Iona, T., Chiodo, S., Valenzano, A., De-Rosas, M., Messina, G., Tessitore, A., \& Cibelli, G. (2017). Salivary alpha-amylase, salivary cortisol, and anxiety during a youth taekwondo championship: An observational study. Medicine, 96(28), e7272.

Casto, K. V., Rivell, A., \& Edwards, D. A. (2017). Competition-related testosterone, cortisol, and perceived personal success in recreational women athletes. Hormones and Behavior, 92, 29-36.

Clark, A., \& Mach, N. (2016). Exercise-induced stress behavior, gut-microbiota-brain axis and diet: a systematic review for athletes. Journal of the International Society of Sports
Nutrition, 13, 43.

Cohen, S., Janicki-Deverts, D., \& Miller, G. E. (2007). Psychological stress and disease. JAMA, 298(14), 1685-1687

Coutts, A. J., Wallace, L. K., \& Slattery, K. M. (2007). Monitoring changes in performance, physiology, biochemistry, and psychology during overreaching and recovery in triathletes. International Journal of Sports Medicine, 28(2), 125-134.

Davis, P., Halvarsson, A., Lundström, W., \& Lundqvist, C. (2019). Alpine Ski Coaches' and Athletes' Perceptions of Factors Influencing Adaptation to Stress in the Classroom and on the Slopes. Frontiers in psychology, 10, 1641.

Deneen, W. P., \& Jones, A. B. (2017). Cortisol and Alpha-amylase changes during an Ultra-Running Event. International Journal of Exercise Science, 10(4), 531-540.

Dickerson, S. S., \& Kemeny, M. E. (2004). Acute stressors and Cortisol responses: a theoretical integration and synthesis of laboratory research. Psychological Bulletin, 130, 355-391

Filaire, E., Alix, D., Rouveix, M., \& Le-Scanff, C. (2007). Motivation, stress, anxiety, and cortisol responses in elite paragliders. Perceptual and Motor Skills, 104(2), 1271-1281.

Filaire, E., Sagnol, M., Ferrand, C., Maso, F., \& Lac, G. (2001). Psycho physiological stress in judo athletes during competitions. The Journal of Sports Medicine and Physical Fitness, 41(2), 263-268.

Filipas, L., Gallo, G., Pollastri, L., \& La Torre, A. (2019). Mental fatigue impairs time trial performance in sub-elite under 23 cyclists. PLoS One, 14(6), e0218405.

Foley, T. D., Koval, K. S., Gallagher, A. G., \& Olsen, S. H. (2019). Potential widespread denitrosylation of brain proteins following prolonged restraint: proposed links between stress and central nervous system disease. Metabolic Brain Disease, 34(1), 183-189.

Freitas, V. H., Nakamura, F. Y., Miloski, B., Samulski, D., \& Bara-Filho, M. G. (2014). Sensitivity of physiological and psychological markers to training load intensification in volleyball players. Journal of Sports Science \& Medicine, 13(3), 571-579.

Gozansky, W. S., Lynn, J. S., Laudenslager, M. L., \& Kohrt, W. M. (2005). Salivary Cortisol determined by enzyme immunoassay is preferable to serum total Cortisol for assessment of dynamic hypothalamic-pituitary--adrenal axis activity. Clinical Endocrinology, 63(3), 336-341.

Guo, T., Ni, Y., Li, Q., \& Hong, H. (2019). 
Han, J. H., Oh, Y. S., Jung, T. W., \& An, C. S. (2011). Change of Stress Hormone in College Student Golfers. The Korean Journal of Sport, 9(4), 165-173

Han, M. U. (2003). The Stressors and Coping Strategies of University Fin Swimmers. Journal of Sport and Leisure Studies, 19, 1485-1502.

Hellgiegel, D. J. W., \& Woodman, R. W. (1992). Organizational behavior (6th ed). St. Paul, MN; West Publishing Company.

Haufler, A. J., Spalding, T. W., Santa Maria, D. L., \& Hatfield, B. D. (2000). Neuro-cognitive activity during a self-paced visuospatial task: comparative EEG profiles in marksmen and novice shooters. Biological Psychology 53, 131 - 160.

Kirschbaum, C., \& Hellhammer, D. H. (1994). Salivary Cortisol in psycho neuro endocrine research: Recent developments and applications. Psychoneuroendocrinology, 19, 313-333

Ko, B. H. (2016). Association of Psychology, Physical Stress Response, and Game Score in National Bowling Team. Graduate School of Sports Science. Dankook University.

Kwon, H. J., Lee, D. H., \& Yoo, H. S. (2015). Relationship among Stress, Intrinsic Motive, and Continuous Participation in College Athletes. Korea Coaching Development Center, 17(4), 109-116.

Lautenbach, F., Laborde, S., Achtzehn, S., \& Raab, M. (2014). Preliminary evidence of salivary Cortisol predicting performance in a controled setting. Psychoneuroendocrinology, 42, 218-224.

Lazarus, R. S. \& Folkman, S. (1984a). Coping and adaptation. In W. D. gentry(Ed.), The handbook of behavioral medicine(pp. 282-325). New York: Guilford.

Lazarus, R. S. \& Folkman, S. (1984b). Stress, appraisal, and coping. New York: Springer.

Lee, C. S. (2013). Effects of Self-Efficacy and Cognitive Appraisals on Emotional States among Adolescent Boxing Athletes in a Pre-Competition. Korean Society of Sport Psychology, 24(3), 105-116.

Levine, S., \& Ursin, H. (1991). What is stress? In: Rivier MR, Koob G, (eds). Stress, Neurobiology and Neuro endocrinology. New York: Marcel Decker.

Lim, B., \& Kim, K. H. (1983). Shooting guide. Seoul: Sinyoung.

Lim, I. S. (2018). Comparative analysis of the correlation between anxiety, salivary alpha amylase, cortisol levels, and athletes' performance in archery competitions. Journal of Exercise Nutrition \& Biochemistry, 22(4), 69-74
McGrath, J. E. (1970). A conceptual formulation for research on stress. In J. E. McGrath(Ed.). Social and psychological factors in stress(pp.14-49), New York: Holt, Rinehart \& Winston.

Mehrsafar, A. H., Strahler, J., Gazerani, P., Khabiri, M., Sánchez, J. C. J., Moosakhani, A., \& Zadeh, A.M. (2019). The effects of mindfulness training on competition-induced anxiety and salivary stress markers in elite Wushu athletes: A pilot study. Physiology \& behavior, 210, 112655.

Nédélec, M., Halson, S., Abaidia, A.E., Ahmaidi, S., \& Dupont, G. (2015). Stress, Sleep and Recovery in Elite Soccer: ACritical Review of the Literature. Sports Medicine, 45(10), 1387-400.

Oh, B. S. (2018). A Study on Cortisol, DHEA, IgA and Stress Perception during Competition of Table Tennis Players in the Middle and High School. Department of Physical Education Graduate School. of Kong-ju National University.

Owens, M. J., Overstreet, D. H., Knight, D. L., Rezvani, A. H., Ritchie, J. C., Bissette, G., Janowsky, D. S., \& Nemeroff, C. B. (1991). Alterations in the hypothalamic-pituitary- adrenal axis in a proposed animal model of depression with genetic muscarinic supersensitivity. Neuropsychopharmacology, 4(2), $87-93$.

Park, J. H., Kim, Y. N., \& Kim, J. Y. (2014). The Effects of Pre-competitive Weight Loss on EEG and Training Stress in College Wrestling Match Contrast Wrestling Athletes. Korea Coaching Development Center, 16(3), 167-173.

Park, K. J., Kang, W. Y., Lee, K. H., \& Koo, M. J. (2012). The Stressors and Coping Strategies of Professional Cycle Racers. Korean Journal of Sport Studies, 51(5), 263-278.

Park, W. J, \& Jung, I. K. (2006). The Effect of Gymnastics Competitive State on the Stress Hormone. The Korea Journal of Sports Science. 15(1), 705-715

Sallen, J., Hemming, K., \& Richartz, A. (2018). Facilitating dual careers by improving resistance to chronic stress: effects of an intervention programme for elite student athletes. European Journal of Sport Science. 18(1), 112-122.

Selye, H. (1984). Stress and Health; A perspective on aging and retirement. Ballinger Publishing Co.

Shields, G. S., Sazma, M. A., \& Yonelinas, A. P. (2016). The effects of acute stress on core executive functions: A meta-analysis and comparison with Cortisol. Neuroscience and Biobehavioral Reviews, 68, 651-668.

Singer, N., Sommer, M., Döhnel, K., Zänkert, S., Wüst, S., \& Kudielka, B. M. (2017) Acute psychosocial stress and 
everyday moral decision-making in young healthy men: The impact of Cortisol. Hormones and Behavior, 93, 72-81.

Smith, R. E. (1986). Toward a cognitive affective model of athletic burnout. Journal of Sport Psychology, 8, 36-80.

Woo, M., \& Kim, Y. (2017). Inter-and Intrahemispheric EEG Coherence and Visuomotor Performance During Shooting
Competition and Practice. Perceptual and motor skills 124, 830-845.

Youm, G. H. (2019). The Influence of Stress on Flow and Burn-out of Middle school Students Majoring in Dance. Korean Journal of Dance, 19(1), 97-106.

\title{
엘리트 사격 선수들이 지각하는 심리적 스트레스와 생리적 스트레스의 관계
}

\author{
박상혁 ${ }^{1}$, 전재연 ${ }^{2}$, 임승택 ${ }^{3}$ \\ 1한국스포츠정책과학원 선임연구위원 \\ 2한국스포츠정책과학원 연구위원 \\ 3강원대학교 연구교수
}

〔목적〕 본 연구의 목적은 엘리트 사격 선수들이 시합 시 경험하는 심리적-생리적 스트레스를 통합적 접근을 통해 선수들이 시합에서 경험하는 스트레스의 올바른 자각을 유도하고 이를 측정함으로써 경기력 향상에 유용 한 정보를 제공하기 위한 목적이 있다. (방법) 본 연구의 대상은 권총 및 소총, 산탄총 등 국가대표 및 엘리트 사격 선수 38 명을 대상으로 남자선수 13 명, 여자선수 25 명으로 선정하였다. 심리 검사지를 이용한 스트레스 측정은 박상혁 (2016)의 엘리트 사격 스트레스 연구에서 탐색 된 스트레스 요인을 기초로 본 연구에 맞게 설문 지를 제작하여 사용하였다. 생리적 스트레스 호르몬 지표인 cortisol은 타액을 이용하여 측정하였다. (결과) 심리 스트레스 하위요인에 대한 신뢰도 사전 사후 분석결과 통계적으로 유의확률은 나타나지 않았다. 시합 전 날의 cortisol의 농도는 $0.1704 \mu \mathrm{g} / \mathrm{dL}$ 로 나타났으며, 시합 직전의 시합 직전의 농도는 $0.3558 \mu \mathrm{g} / \mathrm{dL}$ 로 유 의하게 증가하였다. 상관분석 결과 시합 직전의 cortisol은 시합점수와 부적 상관 $(\mathrm{r}=-.361, \mathrm{p}=.036)$ 으로 나타났으며, 다중회귀 분석의 결과 cortisol의 설명변량은 $13 \%$ 로 나타났다. 〔결론〕 본 연구에서는 생리적 스트레스가 심리적 스트레스에 비하여 선수들의 경기력에 부정적 영향을 미치는 것으로 나타났다.

주요어: 사격, 엘리트 선수, 스트레스, 코티졸, 경기력 향상 
Appendix 1. Correlation analysis results of competition score, psychological stress and cortisol (pre- measurement)

\begin{tabular}{|c|c|c|c|c|c|c|c|c|c|c|c|}
\hline Factors & $\begin{array}{l}\text { Compe- } \\
\text { tition } \\
\text { score }\end{array}$ & cortisol & Effort loss & $\begin{array}{l}\text { Result } \\
\text { burden }\end{array}$ & $\begin{array}{l}\text { Deterioration } \\
\text { of condition }\end{array}$ & $\begin{array}{l}\text { Equipment } \\
\text { problems }\end{array}$ & $\begin{array}{c}\text { Decreased } \\
\text { concentratio } \\
n\end{array}$ & $\begin{array}{c}\text { Major } \\
\text { player's } \\
\text { expectations }\end{array}$ & $\begin{array}{l}\text { Lack of } \\
\text { training }\end{array}$ & $\begin{array}{l}\text { Loss of } \\
\text { confidence }\end{array}$ & Overstrain \\
\hline $\begin{array}{l}\text { Competition } \\
\text { score }\end{array}$ & 1 & .137 & -.123 & -.009 & -.138 & -.054 & -.286 & -.129 & -.019 & .043 & -.083 \\
\hline cortisol & .137 & 1 & .110 & .091 & .318 & .152 & .204 & .161 & .067 & .120 & .259 \\
\hline Effort loss & -.123 & .110 & 1 & $.840^{* *}$ & $.564 * *$ & $.572 * *$ & $.697 * *$ & $.636^{* *}$ & $.624 * *$ & $.773^{* *}$ & $.716^{* *}$ \\
\hline $\begin{array}{l}\text { Result } \\
\text { burden }\end{array}$ & -.009 & .091 & $.840 * *$ & 1 & $.720 * *$ & $.706^{* *}$ & $.574 * *$ & $.595^{* *}$ & $.694 * *$ & $.769^{* *}$ & $.782 * *$ \\
\hline $\begin{array}{l}\text { Deterioration } \\
\text { of condition }\end{array}$ & -.138 & .318 & $.564 * *$ & $.720^{* *}$ & 1 & $.657^{\text {** }}$ & $.628^{* *}$ & $.573^{* *}$ & $.569^{* *}$ & $.667^{* *}$ & $.809^{* *}$ \\
\hline $\begin{array}{l}\text { Equipment } \\
\text { problems }\end{array}$ & -.054 & .152 & $.572^{* *}$ & $.706^{* *}$ & $.657^{* *}$ & 1 & $.586^{* *}$ & $.632 * *$ & $.689 * *$ & $.718 * *$ & $.713 * *$ \\
\hline $\begin{array}{l}\text { Decreased } \\
\text { concentration }\end{array}$ & -.286 & .204 & $.697 * *$ & $.574 * *$ & $.628 * *$ & $.586^{* *}$ & 1 & $.640 * *$ & $.618 * *$ & $.692 * *$ & $.674 * *$ \\
\hline $\begin{array}{c}\text { Major } \\
\text { player's } \\
\text { expectations }\end{array}$ & -.129 & .161 & $.636^{* *}$ & $.595 * *$ & $.573^{* *}$ & $.632 * *$ & $.640 * *$ & 1 & $.645 * *$ & $.728 * *$ & $.605 * *$ \\
\hline $\begin{array}{l}\text { Lack of } \\
\text { training }\end{array}$ & -.019 & .067 & $.624 * *$ & $.694 * *$ & $.569^{* *}$ & $.689^{* *}$ & $.618^{* *}$ & $.645^{* *}$ & 1 & $.744^{* *}$ & $.559^{* *}$ \\
\hline $\begin{array}{c}\text { Loss of } \\
\text { confidence }\end{array}$ & .043 & .120 & $.773^{* *}$ & $.769^{* *}$ & $.667 * *$ & $.718^{* *}$ & $.692 * *$ & $.728 * *$ & $.744 * *$ & 1 & $.765^{* *}$ \\
\hline Overstrain & -.083 & .259 & $.716^{* *}$ & $.782 * *$ & $.809^{* *}$ & $.713^{* *}$ & $.674 * *$ & $.605^{* *}$ & $.559 * *$ & $.765^{* *}$ & 1 \\
\hline
\end{tabular}

Appendix 2. Correlation analysis results of competition score, psychological stress and cortisol (post- measurement)

\begin{tabular}{cccccccccccc}
\hline \hline Factors & $\begin{array}{c}\text { Compe- } \\
\text { tition } \\
\text { score }\end{array}$ & cortisol & Effort loss & $\begin{array}{c}\text { Result } \\
\text { burden }\end{array}$ & $\begin{array}{c}\text { Deterioration } \\
\text { of condition }\end{array}$ & $\begin{array}{c}\text { Equipment } \\
\text { problems }\end{array}$ & $\begin{array}{c}\text { Decreased } \\
\text { concentration }\end{array}$ & $\begin{array}{c}\text { Major } \\
\text { player's } \\
\text { expectations }\end{array}$ & $\begin{array}{c}\text { Lack of } \\
\text { training }\end{array}$ & $\begin{array}{c}\text { Loss of } \\
\text { confidence }\end{array}$ & Overstrain \\
\hline $\begin{array}{c}\text { Competition } \\
\text { score }\end{array}$ & 1 & $-.361^{*}$ & -.005 & .004 & .094 & .233 & .011 & -.153 & -.113 & .100 & .077 \\
\hline cortisol & $-.361^{*}$ & 1 & .326 & .289 & -.050 & -.207 & $.014^{* *}$ & .228 & .122 & .220 & .156 \\
\hline Effort loss & -.005 & .326 & 1 & $.943^{* *}$ & $.680^{* *}$ & $.596^{* *}$ & $.762^{* *}$ & $.750^{* *}$ & $.634^{* *}$ & $.892^{* *}$ & $.835^{* *}$ \\
\hline Result burden & .004 & .289 & $.943^{* *}$ & 1 & $.697^{* *}$ & $.631^{* *}$ & $.780^{* *}$ & $.837^{* *}$ & $.702^{* *}$ & $.880^{* *}$ & $.868^{* *}$ \\
\hline $\begin{array}{c}\text { Deterioration } \\
\text { of condition }\end{array}$ & .094 & -.050 & $.680^{* *}$ & $.697^{* *}$ & 1 & $.761^{* *}$ & $.769^{* *}$ & $.628^{* *}$ & $.601^{* *}$ & $.682^{* *}$ & $.808^{* *}$ \\
\hline $\begin{array}{c}\text { Equipment } \\
\text { problems }\end{array}$ & .233 & -.207 & $.596^{* *}$ & $.631^{* *}$ & $.761^{* *}$ & 1 & $.786^{* *}$ & $.526^{* *}$ & $.665^{* *}$ & $.657^{* *}$ & $.739^{* *}$ \\
\hline $\begin{array}{c}\text { Decreased } \\
\text { concentration }\end{array}$ & .011 & .014 & $.762^{* *}$ & $.780^{* *}$ & $.769^{* *}$ & $.786^{* *}$ & 1 & $.720^{* *}$ & $.773^{* *}$ & $.802^{* *}$ & $.740^{* *}$ \\
\hline $\begin{array}{c}\text { Major player's } \\
\text { expectations }\end{array}$ & -.153 & .228 & $.750^{* *}$ & $.837^{* *}$ & $.628^{* *}$ & $.526^{* *}$ & $.720^{* *}$ & 1 & $.666^{* *}$ & $.745^{* *}$ & $.768^{* *}$ \\
\hline $\begin{array}{c}\text { Lack of } \\
\text { training }\end{array}$ & -.113 & .122 & $.634^{* *}$ & $.702^{* *}$ & $.601^{* *}$ & $.665^{* *}$ & $.773^{* *}$ & $.666^{* *}$ & 1 & $.713^{* *}$ & $.611^{* *}$ \\
\hline $\begin{array}{c}\text { Loss of } \\
\text { confidence }\end{array}$ & .100 & .220 & $.892^{* *}$ & $.880^{* *}$ & $.682^{* *}$ & $.657^{* *}$ & $.802^{* *}$ & $.745^{* *}$ & $.713^{* *}$ & 1 \\
\hline \begin{tabular}{c} 
Overstrain \\
\hline \hline
\end{tabular} & .077 & .156 & $.835^{* *}$ & $.868^{* *}$ & $.808^{* *}$ & $.739^{* *}$ & $.740^{* *}$ & $.768^{* *}$ & $.611^{* *}$ & $.773^{* *}$ & 1 \\
\hline
\end{tabular}

